\title{
1. A brief history of public debt
}

A concise history of public debt is a prerequisite to understanding its causes and consequences. Historical context helps corroborate or confute alternative theories and analytical methods. The good news is that hard data on public debt and its history have become more comprehensive, more accurate, and more readily available in recent years. ${ }^{1}$ Unfortunately, much contemporary analysis is overly formal, non-empirical, or focused myopically on a narrow subset of public debt history that's not representative of its timeless and valid principles. By one selective reading public debt may appear sinful, wasteful, and burdensome - by another, moral, productive, and beneficial - and by another still, neither harmful nor beneficial but merely innocuous.

\subsection{FINANCE IN ANCIENT AND MEDIEVAL TIMES}

Governments in ancient and medieval times required funding, as do modern states, but they didn't borrow "publically" in the sense of drawing funds from a wide populace and making it ultimately responsible for servicing the debt (paying principal and interest), as a form of deferred taxes. Homer and Sylla (1991) show that private borrowing existed since recorded history and preceded the development of public borrowing by many centuries. Eventually, public borrowing became common, but initially involved loans in kind (commodities) instead of in money, for shorter rather than longer periods, and for war or idiosyncratic purposes rather than as a permanent funding source. In ancient and medieval times no debt instruments existed in the forms so familiar to us today - namely, tangible securities traded in secondary, liquid markets with prices and yields visible on public exchanges. This form of sovereign obligation emerged in the late seventeenth century, when the rule of law, sanctity of contract, and parliamentary checks on monarchical power took hold, after Britain's Glorious Revolution in $1688 .^{2}$

In the pre-commercial feudal era, princes, landlords, and clerics owned estates or sanctuaries that generated income, not unlike a personal business, but by command-and-control operations, with tribute paid by tenant 
farmers or serfs, in return for military protection. ${ }^{3}$ Government funds in the feudal era also derived from the spoils of conquest and war, from the sale of offices, titles, and indulgences, or by debasing coins at the mint. Prior to the Renaissance, whenever monarchs, princes, and popes borrowed they did so on their own account, pledging personal income and estates as security. They often reneged on their debts. Creditors, initially lured by the prospect of large financial gains, given their privileged proximity to political power, more often than not were mistreated, whether by defaults, interest reductions, confiscations, or bodily harm. ${ }^{4}$

In an early account of sovereign debt in ancient times, Bullock (1930) describes how in the fourth century BC, Dionysus of Syracuse borrowed from citizens but "repaid" the loan only by debasing the coinage. Today this is called an implicit (or indirect) default, in contrast to an explicit or direct one; principal and interest are still paid, but not in the initially promised medium of exchange. Governments still resort to this ruse today, as all now issue fiat paper money. In recent decades a few have issued inflation-indexed public bonds (the United Kingdom since 1982, the United States since 1997), mainly for information purposes or as policy guides; they are not a major part of total issuance. The old-fashioned term "debasement" has been out of favor for at least a century; today the tactic is known as "inflationary finance" and the only remaining analytical controversy is whether public creditors offset its effects by requiring higher yields.

Even though credit-debtor relations developed in ancient times, they stagnated and reversed in the dark ages and medieval period, due to a persistent animosity not only to money-making and commerce but also to usury (Munro, 2003). Originally usury meant lending money at an interest rate, not merely at a high rate. ${ }^{5}$ Aristotle had declared money "barren," or unproductive, so interest was an exploitation or theft (Meikle, 1994), but the ancients were not nearly as hostile to it as their religious successors subsequent to the fall of the Roman Empire. For a millennium all major religions condemned, forbade, and punished money-making and lending at interest.

Eventually Aquinas provided a qualified defense of lending, which coincided with the origin and growth of modern, private banking and lending, starting in Italy and spreading quickly to Spain and Holland. With the Protestant Reformation came an unlikely defense of usury, by Martin Luther (1524 [1897]). In the Enlightenment of the eighteenth century, after commerce and lending at interest emerged and flourished for nearly two centuries, usury received a robust, unqualified defense by Bentham (1787), which the classical economists - from Smith to Ricardo and Say and Mill - heartily endorsed. Without a more favorable 
attitude toward lending at interest, there would not have been so great an increase in debt of any kind, including public debt. The more favorable philosophical-cultural attitude toward economic activity and capital accumulation in general that was so characteristic of the Renaissance and Enlightenment also made available more lendable funds. Yet the latent and age-old (ancient-medieval) animosity toward bankers and lenders has never totally dissipated; it was revived in the mid-nineteenth century by Karl Marx, with his prejudice against "rentiers" as parasites who induce a late, crisis-ridden phase of capitalism, "finance capitalism." Antagonism towards creditors made it easier (and morally obligatory) for overextended borrowers, mainly sovereigns, to renege on debts or demand forgiveness. ${ }^{7}$ In contrast, under the classical gold standard era (1870-1913) sovereigns were better behaved, more credible, and more creditworthy. ${ }^{8}$

Prior to the seventeenth-century Renaissance and eighteenth-century Enlightenment in Europe, lending to governments meant lending personally to rulers, usually monarchs or popes (Cahill, 2010). But these were largely the personal debts of the rulers, incurred mainly to wage war, repel invasion, or fund infrastructure projects; technically they were not "public" debts, in the sense of being based on the paying capacity of the general public. These were state debts, repayable from the spoils of war or by the crown's tax revenues or wealth transfers. Instead of relying on the precarious practice of borrowing funds under emergency settings like war, monarchs, princes, and popes preferred instead to amass riches and armies in advance.

Indeed, mercantilism as a system not only of protectionism and regulation but also of public finance, precisely favored policies that built up, ex ante, the cash holdings of the king and his nation-state, if necessary at the expense of citizens or other nations. The aim of a "favorable balance of trade," or net exports of goods in excess of their importation, was a net importation of money (or specie). In this way a monarch amassed a "war chest" and didn't have to borrow. In France, mercantilism was personified in finance minister Colbert (1619-83). The German counterpart to mercantilism was Cameralism, or the art and science of efficiently administering royal finances.

\subsection{THE FINANCIAL REVOLUTION AND THE ENLIGHTENMENT}

The origin and development of today's modern system of public finance was made possible by the rise of constitutionally limited, representative government, especially in the wake of Britain's Glorious Revolution 
in 1688 and America's Revolution in 1776 (Fisk, 1920). Each was a revolt not of peasants or serfs but of the rich and elites (taxpayers and rentiers) who were fed up with incessant royal land grabs, arbitrary exactions, cavalier loan defaults, and opportunistic debasements of official coinage. Parliamentary restraint on the arbitrary powers of royals shifted the focal point of public finance from the personal finances of monarchs to the financial capacity of the populace and economy at large. Thereafter, government spending, taxing, and borrowing would be undertaken on behalf of the public; instead of bending to royal edicts or caprice, public finance practices thereafter would hew to regular and predictable commercial customs.

The financial revolution of the seventeenth and eighteenth centuries, which preceded and made possible the Industrial Revolution of the eighteenth and nineteenth centuries, entailed greater reliance on rulebased systems and procedures among creditors and debtors, a greater standardization of debt instruments and securities, and secondary markets where such securities could be traded, rendered more liquid as collateral for further borrowing. ${ }^{9}$ As debt securities became publicly traded and more visible, so also did their prices and yields; a transparent window was opened on the reputation and credibility (or lack thereof) of debtors generally, and sovereign debtors in particular recognized that they could, by credible commitment and demonstrated creditworthiness, borrow more easily and regularly at lower interest rates relative to rivals, and that borrowing power could be enormously advantageous in wartime, when debt finance was politically preferable to higher taxes. No longer was it necessary to accumulate royal riches in advance. After 1650 public borrowing began in earnest in the Italian republics of Genoa and Venice, next in the United Provinces (Netherlands), and soon thereafter (especially after 1688) in England and France (Fritschy, 2003; Carlos and Neal, 2011).

History makes clear that during the multi-century, post-medieval shift from absolute monarchies to today's virtually unrestrained democracies, there existed, in the eighteenth and nineteenth centuries, a third and better way: constitutionally limited commercial republics (the United States included) where rights were respected most and economies performed best (MacDonald, 2003). There public credit was sound because the state itself was restrained. Suffrage was limited and representatives were "natural" aristocrats (manufacturers, merchants, bankers) not the lawyers or political careerists drawn from all too common pools. The "Republic of Rentiers" (my own nomenclature) properly and profitably eschewed the capriciousness and chaos common to autocracy and democracy alike.

The transition from arbitrary rule by whim and by men to rule by pre-established legal precedent fostered a vast expansion of credit-debtor 
relations, including those between government (as debtor) and private creditors. Whereas most public debt scholars have argued that more representative forms of constitutional government encouraged responsible public debt issuance, some argue a reverse causation - that burgeoning public debt itself expanded democracy and freedom (ibid.). But the past century has seen not merely a vast extension in suffrage and more direct forms of democracy, but also the spread of public fiscal imprudence. ${ }^{10}$ In the eighteenth and nineteenth centuries, public debt expanded mainly during wartime, then contracted in peacetime, relative to national income, but in the more democratic past century, deficit spending and high public debt ratios have become the norm, despite cyclicality and wars, and rise even in peacetime.

Of great importance to the historical development of public debt, during the Renaissance, private banks shifted from providing mere warehouse services for clients' specie into fractional-reserve institutions that lent a portion of deposits at interest, with assets now a mixture of precious metals and loans - what Carroll (1855-79 [1964]) called the "organization of debt into currency." Instead of currency backed by specie only, it was backed by specie plus debts owed to banks by borrowers. Initially currency was still redeemable at a fixed weight of specie, and not as yet monopolized by government or issued by states without backing (as we have today). This manner of backing currency partly with debt was eventually and gradually adopted by money-issuing central banks.

During the first two centuries of public debt issuance (the eighteenth and nineteenth centuries) coupon rates were low relative to prior experience, typically 3-6 percent (Homer and Sylla, 1991), because most sovereigns were fiscally prudent. They issued large sums of debt amid war, but otherwise eschewed chronic budget deficits. In peacetime they also used various pre-commitment devices - sinking funds, annuities, and the gold standard - to assure creditors of timely repayment in money that would hold its value over time. ${ }^{11}$

For much of US history the federal government employed sinking funds to enhance the credibility of its commitment to service its debts. Annual budget appropriations would include a set-aside of sums to accumulate in an escrow-type fund to be used to repay the principal of public debt at maturity. The fund was also used to periodically purchase undervalued public bonds; the Treasury could selectively redeem those of its bonds that were trading below par, which boosted bond prices and investor confidence. Public bond prices were less volatile, thus more attractive to hold. Public annuities were also used; instead of paying interest only during the life of a public bond, then a single, large principal payment at maturity, an annuity paid both interest and a steady portion of the principal 
semi-annually, eliminating the burden of repaying a huge lump sum of principal at maturity. Like sinking funds, annuities were a credible means of prudent public borrowing, which permitted sovereigns to borrow more at lower rates, without either financial repression or unorthodox central bank policies.

The sinking fund method had been used in England and was inaugurated by new US Treasury Secretary Alexander Hamilton in 1790 to enhance the trustworthiness of an erstwhile bankrupt government. Britain ceased resorting to sinking funds in the late 1800s, while the United States discontinued their use (along with the classical gold standard) in the 1930s. In time, sinking funds became prone to political abuse and manipulation; accumulated sums initially earmarked for repayment of principal, years hence, proved tempting to populist politicians wishing to spend the money sooner than later, and on more democratic purposes than a return of capital to bondholders. With sinking funds depleted, public bonds became "unfunded," as are public contingent liabilities today.

\subsection{VISUALIZING THE HISTORY OF PUBLIC DEBT}

Visual depictions of the history of public debt provide perspective on what has occurred in the West over the past three centuries - and why. The longest-term data are available for the United Kingdom and United States, but data for other major countries are available since 1870 .

For the United Kingdom since the Glorious Revolution in 1688, Figure 1.1 illustrates the long-term trend in the public debt/GDP ratio. Today's ratio of 50 percent is well below the all-time high of 255 percent recorded at the end of the Napoleonic Wars (1815), and also below the ratio recorded immediately after World War II (230 percent). Britain's public debt ratio climbed steadily and precipitously amid repeated and costly wars between 1700 and 1815 , but then declined just as precipitously during the relatively peaceful and prosperous century that lasted from 1815 to 1914 . Today's debt ratio, at 50 percent, is roughly where it was before the large run up in public debt associated with World War I and World War II. Certainly the British government has engaged in chronic deficit spending in recent decades, but Figure 1.1 makes clear that it has not done so in excess of growth in national income.

Figure 1.2 illustrates the interest expense that has been incurred by the British government on its public debt since 1700, also measured as a percentage of national income. The pattern is similar to that seen in Figure 1.1: public interest expense has been high when the public debt ratio has been high, and low when the debt ratio has been low. Today Britain's 


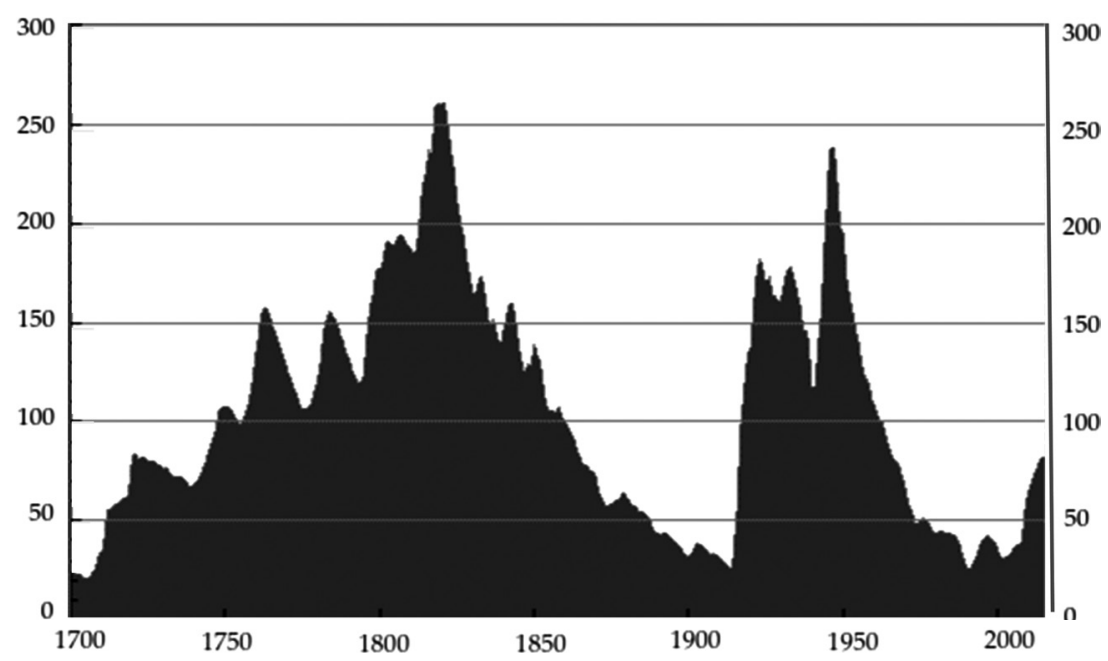

Source: www.ukpublicspending.com.

Figure 1.1 Public debt of the United Kingdom as a percentage of GDP, 1700-2015

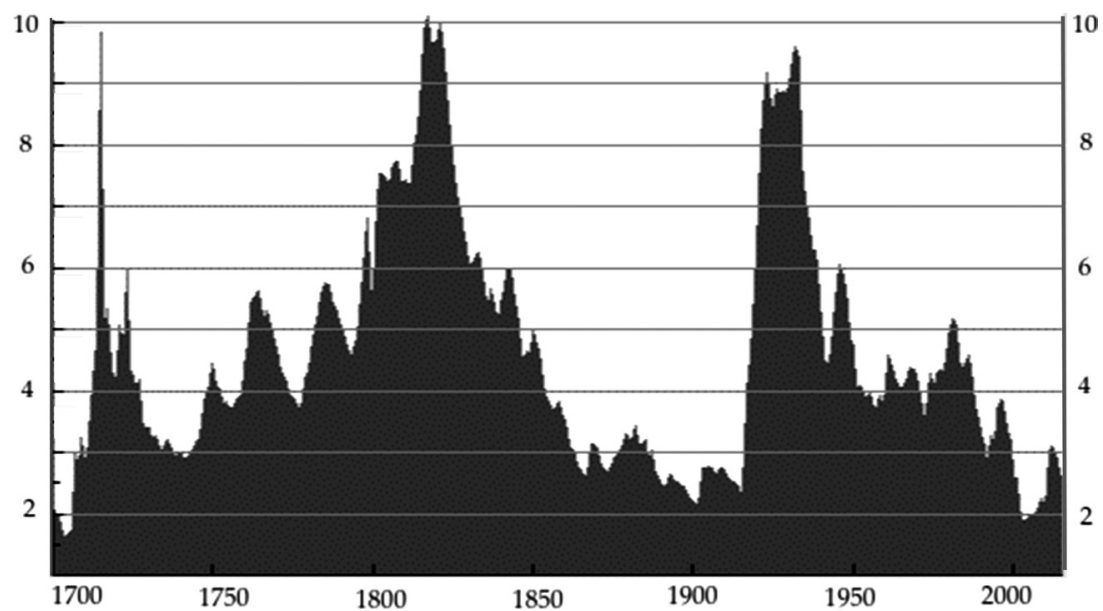

Source: www.ukpublicspending.com.

Figure 1.2 Public interest expense of the United Kingdom as a percentage of GDP, 1700-2015 


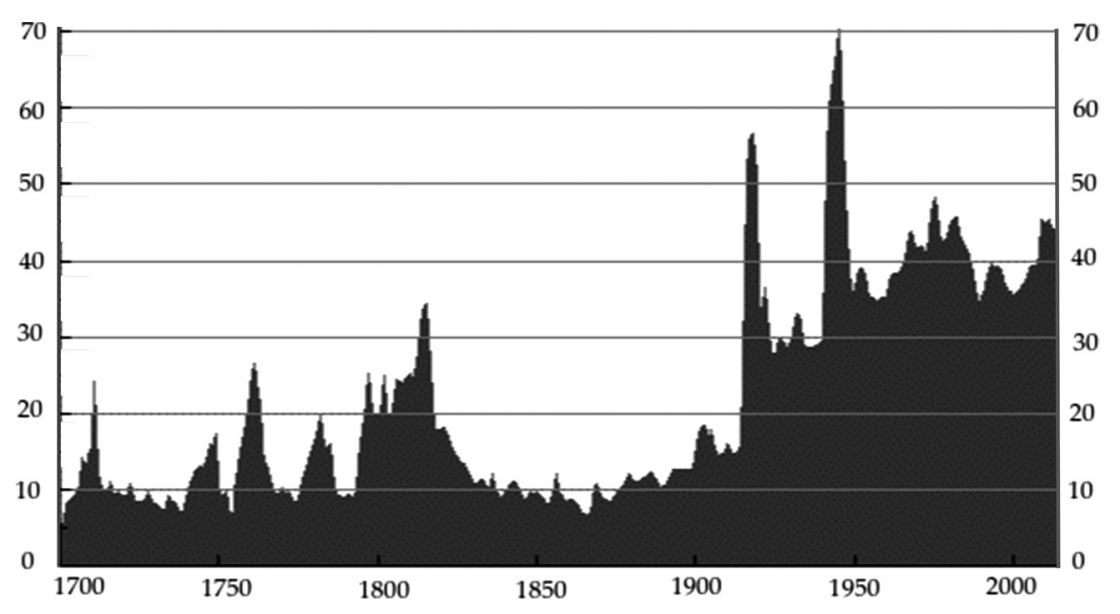

Source: www.ukpublicspending.com.

Figure 1.3 Public spending of the United Kingdom as a percentage of GDP, 1700-2015

public interest expense is a mere 2.2 percent of its annual GDP, or less than a quarter of the 9.5 percent burden felt at the end of World War II and the still higher burden of 10 percent recorded at the end of the Napoleonic Wars in 1815. Indeed, today's ratio of 2.2 percent is lower than the ratio of 2.5 percent seen prior to the multi-year expansion of public debt that began a century ago on the eve of World War I.

Figure 1.3 plots the long-term ratio of annual government spending in the United Kingdom, also as a percentage of annual national income (GDP). We see a saw-toothed but upward climb in the relative size of the British government between 1700 and 1815, but then a long-term decline from roughly 33 percent of the economy in 1815 to less than 10 percent between 1850 and 1900. The spending share reaches the astounding heights of 57 percent amid World War I and 70 percent amid World War II, but today's share, at 41 percent, is almost half the level of the previous record high and, despite increases in the role and scope of the British welfare state, the spending share has generally declined from 48 percent in 1981 .

Figure 1.4 shows the long-term trend in the public debt/GDP ratio of the United States soon after its founding in 1790. Today's ratio is 100 percent, nearly triple the recent low of 35 percent in 1982, but also below the all-time high of nearly 120 percent set in World War II. Wars have been the main cause of spikes in the US debt ratio - up to 18 percent at the end of the war of 1812 , to 34 percent by the end of the Civil War, 37 percent at the end of 


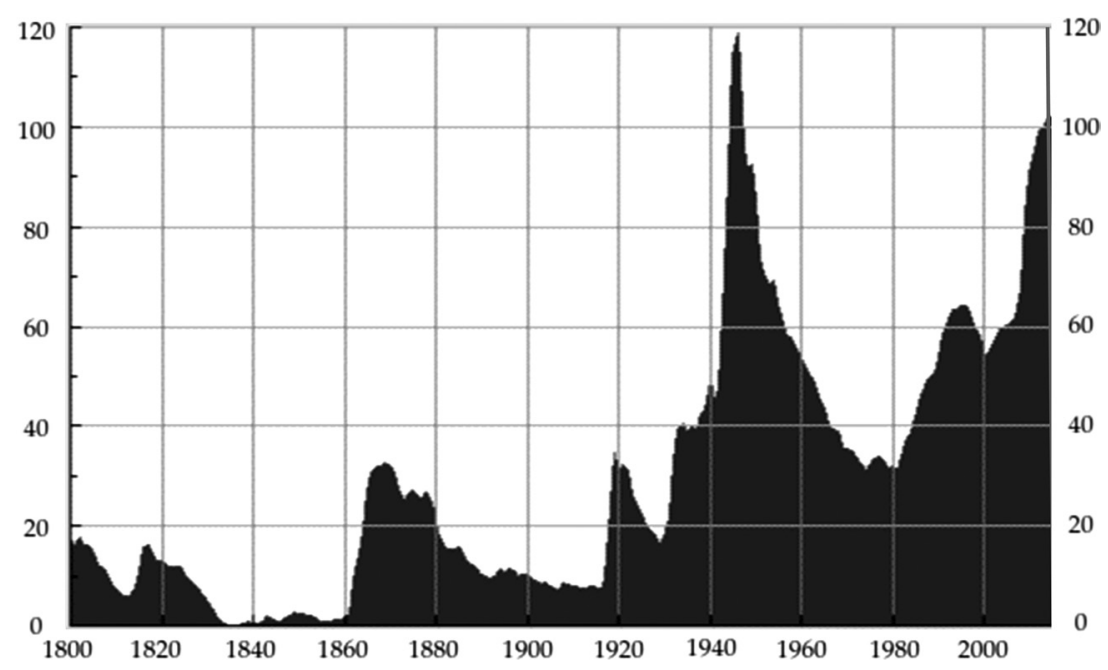

Source: www.usgovernmentspending.com.

Figure 1.4 Public debt of the United States as a percentage of GDP, 1800-2015

World War I, and 125 percent after the end of World War II. The latest rise in the US debt ratio might also be attributed to war, to the "war on terrorism," which has been more expensive (inflation-adjusted) than all prior US wars except World War II. The secular rise in the debt ratio since 1975 also reflects entitlement spending.

The more recent, dramatic rise in the US debt ratio is due to the large revenue loss and deficit spending associated with the financial crisis and Great Recession (2008-09) and thus more resembles the period of banking failures and Great Depression of the 1930s, when the US debt ratio doubled from 18 percent to 36 percent. Thereafter, due to the deficit spending associated with World War II, it tripled from 36 percent to 125 percent.

Figure 1.5 plots US public interest expense as a portion of GDP since 1800. Despite a high debt ratio lately (Figure 1.4), the interest-expense ratio remains relatively low, at 1.4 percent, because the average interest rate on US public debt has been very low compared to prior decades (1980s and 1990s). The record ratio occurred in the late 1980s, when the US debt ratio was only 68 percent but interest rates were much higher. From 1985 to 1990 the US ten-year Treasury bond yield averaged 8.75 percent, but over the past five years, even under a much higher debt ratio, it has averaged a mere 3.25 percent. 


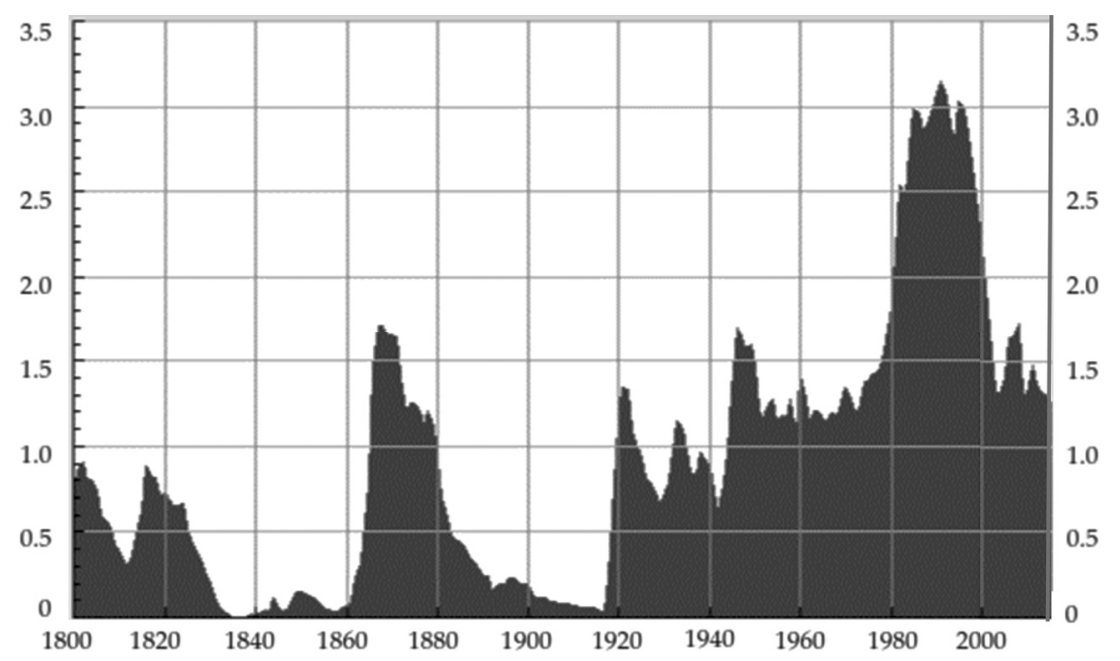

Source: www.usgovernmentspending.com.

Figure 1.5 Public interest expense of the United States as a percentage of GDP, 1800-2015

Figure 1.6 shows that US federal spending is now 20 percent of GDP, versus a 41 percent share in Britain, but the US share is up sharply from 17 percent a decade ago. Nevertheless, the all-time high spending share was 48 percent, amid World War II.

The United Kingdom and United States, although the biggest and steadiest public borrowers, in absolute terms, over the past few centuries, aren't the only public borrowers. Figure 1.7 depicts the debt ratios of 22 advanced OECD nations since 1900. As in the UK and US figures, spikes in public leverage ratios accompany World War I (1914-18), the Great Depression (1930s), and World War II (1940-45), but also the recent peacetime period. The ratio at present is 90 percent, up from a low of 23 percent in the mid-1970s and nearly double the 52 percent share in 2007 , prior to the onset of the Great Recession.

Table 1.1 provides more historical context on public debt, depicting trends in public debt/GDP ratios for 15 developed nations over the past century. The highest ratio is that of Japan, nearly 226 percent in 2010, up from 68.0 percent when its stock market and economy peaked in 1990, and versus 8.5 percent in 1970. The second largest ratio in 2010 is Italy's, at 117.5 percent, up steadily from 96.3 percent in 1990 and 30.9 percent in 1970 . Australia now has the lowest debt ratio - at 


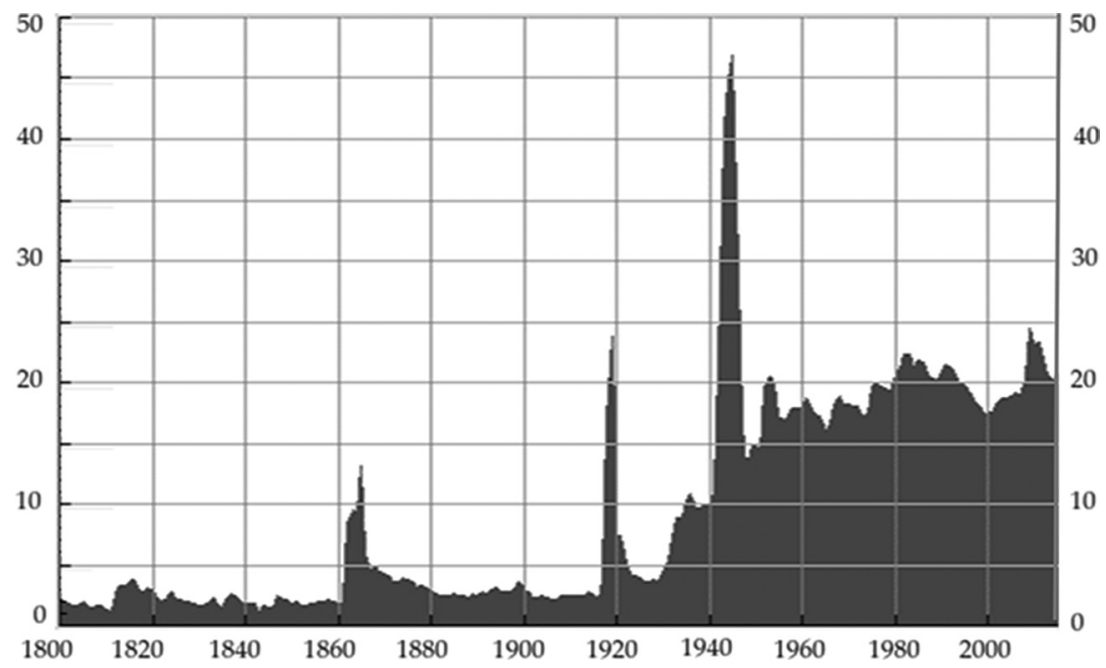

Source: www.usgovernmentspending.com.

Figure 1.6 Public spending of the United States as a percentage of GDP, 1800-2015

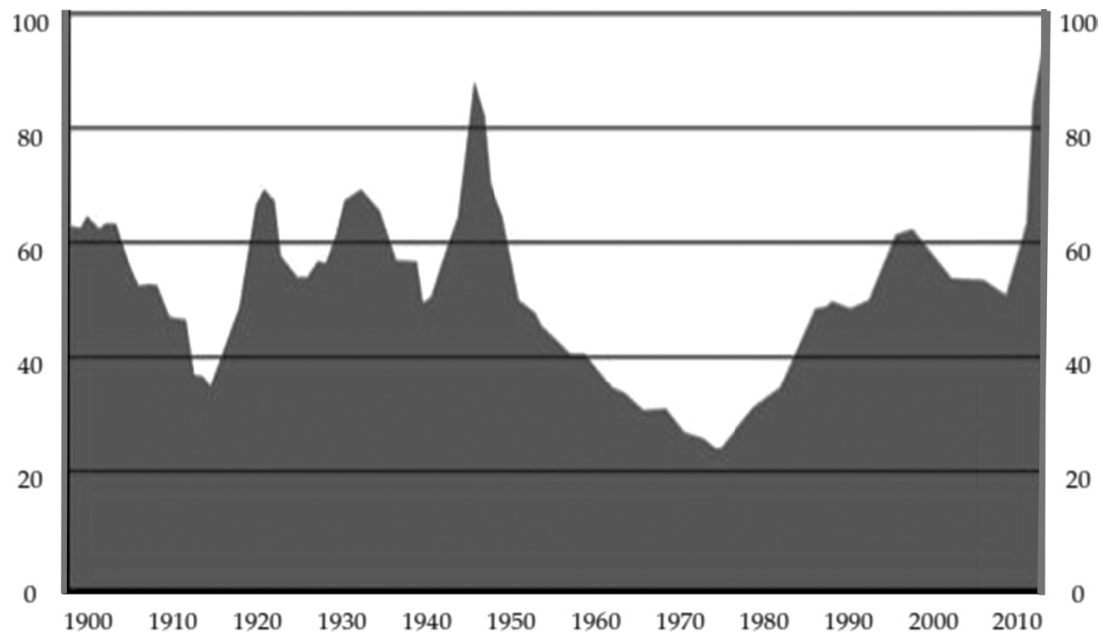

Source: Reinhart (2012, Figure 1).

Figure 1.7 Public debt of 22 OECD nations as a percentage of GDP, 1900-2011 


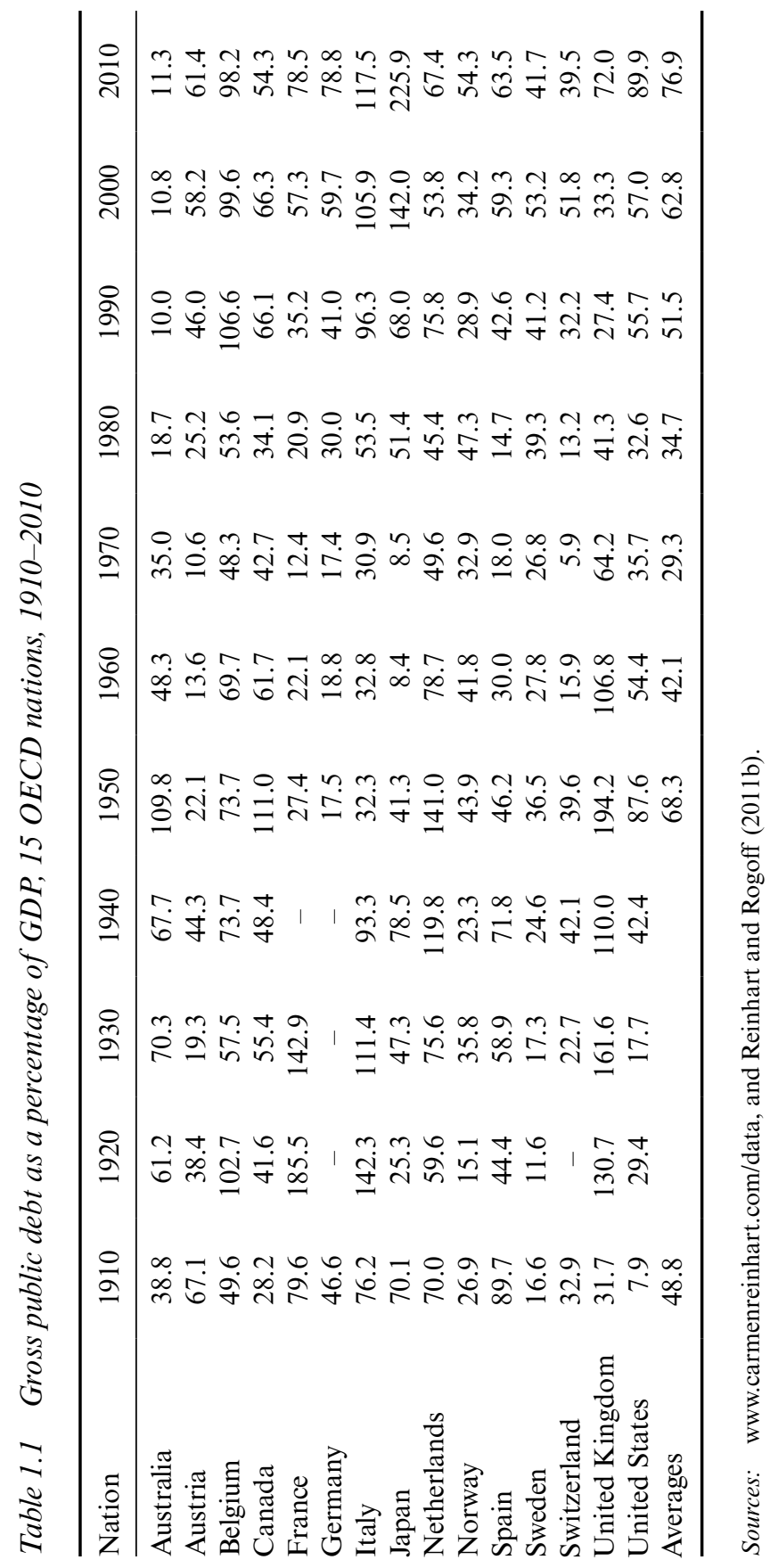


Table 1.2 Public spending as a percentage of GDP, 15 OECD nations, 1910-2010

\begin{tabular}{lrrrrrrrr}
\hline Nation & 1910 & 1920 & 1940 & 1960 & 1980 & 1990 & 2000 & 2010 \\
\hline Australia & 16.5 & 19.3 & 14.8 & 21.2 & 34.1 & 34.9 & 34.8 & 36.3 \\
Austria & 17.0 & 14.7 & 20.6 & 35.7 & 48.1 & 38.6 & 52.2 & 53.0 \\
Belgium & 13.8 & 22.1 & 21.8 & 30.3 & 58.6 & 54.8 & 49.1 & 53.0 \\
Canada & 15.1 & 16.7 & 25.0 & 28.6 & 38.8 & 46.0 & 41.1 & 43.8 \\
France & 17.0 & 27.6 & 29.0 & 34.6 & 46.1 & 49.8 & 51.6 & 56.2 \\
Germany & 14.8 & 25.0 & 34.1 & 32.4 & 47.9 & 45.1 & 45.1 & 46.7 \\
Italy & 17.1 & 30.1 & 31.1 & 30.1 & 42.1 & 53.4 & 46.1 & 50.6 \\
Japan & 8.3 & 14.8 & 25.4 & 17.5 & 32.0 & 31.3 & 39.0 & 40.7 \\
Netherlands & 9.0 & 13.5 & 19.0 & 33.7 & 55.8 & 54.1 & 44.2 & 51.2 \\
Norway & 9.3 & 16.0 & 11.8 & 29.9 & 43.8 & 54.9 & 42.3 & 46.0 \\
Spain & 11.0 & 8.3 & 13.2 & 18.8 & 32.2 & 42.0 & 39.1 & 45.0 \\
Sweden & 10.4 & 10.9 & 16.5 & 31.0 & 60.1 & 59.1 & 55.1 & 53.1 \\
Switzerland & 14.0 & 17.0 & 24.1 & 17.2 & 32.8 & 33.5 & 35.1 & 33.7 \\
United Kingdom & 12.7 & 26.2 & 30.0 & 32.2 & 43.0 & 39.9 & 36.6 & 53.1 \\
United States* & 7.5 & 12.1 & 19.7 & 27.0 & 31.4 & 33.3 & 33.9 & 42.3 \\
Averages & 12.9 & 18.3 & 22.4 & 28.0 & 43.1 & 44.7 & 43.0 & 47.0 \\
\hline
\end{tabular}

Note: * Includes federal, state, and local government spending for comparability.

Sources: 1910-80: Tanzi and Schuknecht (2000); thereafter, OECD Factbooks.

11.3 percent, compared to the 15 -nation average of 76.9 percent, more than double its level in 1970 (29.3 percent), yet not much above its level in 1950 (68.3 percent).

The main cause of rising public leverage can be found in Table 1.2, which shows public spending (as a percentage of GDP) by the same 15 nations over the same past century. The trend is clearly upward. On average, only 12.9 percent of GDP was spent a century ago; in 2010 the proportion was 47.0 percent. Today's highest spender is France (56.2 percent), while the lowest is Switzerland (33.7 percent). Bucking the trend, four nations since 1980 have reduced spending as a share of GDP: Belgium, Germany, Netherlands, and Sweden. The biggest increases since 1980 have occurred in Spain $(+12.8$ percentage points, to 45.0 percent), the United States ( +10.9 percentage points, to 42.3 percent), France ( +10.1 percentage points, to 56.2 percent), and the United Kingdom (+10.1 percentage points, to 53.1 percent). Japan has a relatively low spending share ( 40.7 percent), but that's more than double the level of 1960; that Japan's public leverage today is the highest among 
Table 1.3 The paradox of profligacy: higher public debt leverage, yet lower borrowing rates, G-7 nations, 1980-2015

\begin{tabular}{|c|c|c|c|c|c|c|c|c|c|c|}
\hline \multirow[t]{2}{*}{ Nation } & \multicolumn{5}{|c|}{$\begin{array}{c}\text { Gross Public Debt as a \% } \\
\text { of GDP }\end{array}$} & \multicolumn{5}{|c|}{$\begin{array}{l}\text { Ten-year Sovereign } \\
\text { Bond Yields }\end{array}$} \\
\hline & 1980 & 1990 & 2000 & 2010 & 2015 & 1980 & 1990 & 2000 & 2010 & 2015 \\
\hline & & 68.0 & 142.0 & 225.9 & 249.7 & & & & 1.3 & \\
\hline al & 53.5 & 96.3 & 105.9 & 117.5 & 122 & 15.3 & 13.5 & 5. & 4.0 & \\
\hline USA & 32.6 & 55.7 & 57.0 & 89.9 & 105 & 11 & 8.6 & 6. & 3. & \\
\hline UK & 41.3 & 27.4 & 33.3 & 72.0 & 92.2 & 13.8 & 11.1 & 5.2 & 3.9 & 1.9 \\
\hline France & 20.9 & 35.2 & 57.3 & 78.5 & 89. & 13.0 & 9.9 & 5.5 & 3.3 & 0.9 \\
\hline Canada & 34.1 & 66.1 & 66.3 & 54.3 & 78.8 & 12.1 & 10.8 & 5.9 & 3.5 & 1.5 \\
\hline Germany & 30.0 & 41.0 & 59.7 & 78.8 & 74.4 & 8.5 & 8.9 & 5.2 & 2.9 & 0.5 \\
\hline Averages & 37.7 & 55.7 & 74.5 & 102.4 & 116.0 & 11.9 & 10.0 & 5.0 & 3.2 & 1.3 \\
\hline
\end{tabular}

Sources: OECD, IMF, and www.carmenreinhart.com/data.

advanced nations (250 percent, per Table 1.3 ) is due partly to relatively faster spending but also to slower revenue growth since its economy effectively peaked in 1989 .

Despite abundant evidence of sharp increases in public spending shares of GDP in recent decades, with a concomitant expansion in deficit spending and public leverage, Table 1.3 reveals how this has not translated into higher public borrowing costs. In the private sector, all else equal, greater leverage entails a greater risk of debt default, which in turn induces creditors to demand compensation in the form of higher yields. Yet Table 1.3 makes clear that even though public debt ratios for the G-7 nations have increased steadily in recent decades - from an average of 37.7 percent in 1980 to 74.5 percent in 2000 and 116.0 percent in 2015 - their average benchmark (ten-year) Treasury yields have decreased - from an average of 11.9 percent to 5.0 percent in 2000 and just 1.3 percent in 2015 . I designate this odd phenomenon the "paradox of profligacy," and seek to explain it later in the book (Chapter 5). It could be argued that inordinately low bond yields reflect a rational market's view that no profligacy exists in fact, or instead that profligacy prevails but yields have moved lower due to a multi-decade disinflation and, more recently, to financial repression and central banks' zero interest rate policies.

No history of public debt can exclude the increasing role of central banks, which issue a government's monopolized money and underwrite its bonds. Once deemed "lenders of last resort" to private banks, they now also act as lenders of last resort to profligate governments. The power 
and reach of central banking expands virtually without limit with each new decade, especially amid the crises it instigates. Public debt analysts now routinely consolidate the balance sheets of central banks and their needy sovereigns, treating them as one. Central bank "independence" from politics and finance ministries, once considered the sine qua non of proper policymaking, is now a mere shibboleth.

To many economists and historians, the spread of central banking and fiat paper money systems in the past century was a "fix" for a "market failure" in free banking and the gold standard. Yet the origins and evolution of central banking suggest otherwise. Most central banks originated in a sovereign's desperate need to secure funds that it couldn't otherwise obtain by taxes or voluntarily loans. Some began as private banks compelled to lend to deadbeat sovereigns; upon becoming insolvent due to defaults on public loans, they were conveniently nationalized and transformed into government-privileged central banks with monopoly control over fiat currencies that eventually displaced gold and silver in private bank reserves and as circulating media. This was the pattern by which most modern central banks were established, including the first two, in the late seventeenth century: the Swedish Riksbank, established in 1688 upon the takeover of a private bank initially founded in 1656 but which failed, and Britain's Bank of England, established in 1694 as a means of financing yet another war with France.

Britain's modern public debt was launched when William III arranged for the sale of public debt through a syndicate of London merchants; in time this syndicate was formed into the Bank of England. In similar ways and for the same purpose - financial support for the state - central banks were established in Denmark (1773), France (1800), Austria (1816), Norway (1816), Belgium (1850), Netherlands (1864), Germany (1875), Japan (1882), Italy (1893), Switzerland (1905), the United States (1913) and Canada (1933). ${ }^{12}$

Until the 1930s major central banks issued currency redeemable into a fixed weight of gold, and governments in industrially advanced nations pledged to redeem their bonds in gold-convertible money. But since central banks were established mainly to assist governments in funding, ${ }^{13}$ they also purchased large sums of public debt - especially in wartime - and used that asset as a basis for money creation. In this way the classical gold coin standard (1870-1913) was abandoned, amid World War I, in favor of the more centralized gold bullion standard, which in turn was abandoned in 1933 amid the Great Depression. That was followed by a paper-based gold exchange standard (the Bretton Woods system), whereby the US dollar was the worldwide reserve currency and the only one redeemable in gold (albeit solely for other central banks). Since the abandonment of 
the Bretton Woods system in 1971 no central bank resumed issuance of any currency redeemable in gold, for anyone; all such banks have issued only fiat paper money. Initially, in the 1970s, the severing of currencies from gold caused higher inflation expectations and fast-rising public bond yields, but over the past four decades yields on advanced nation sovereign bonds, with exceptions, have steadily declined.

Today's global monetary system, which is less integrated than it was a century ago, due to the international gold standard, entails no effective limit on central banks' power and willingness to create fiat money, which permits public debt and leverage to reach heights unseen historically. In the past decade major central banks have purchased vast new sums of public debt by creating reserves or currency - a method once described as "debt monetization" and "inflationary finance," but lately referred to as "quantitative easing." So far the procedure hasn't boosted inflation or public bond yields, because central banks (in Japan, the United States, Europe, and elsewhere) have also brought down short-term policy rates to near zero percent or even negative, purportedly to stimulate economies, but more probably, to ensure low yields on public debt and thereby forestall the budgetary pressure associated with fast-rising interest expense.

\subsection{QUESTIONS OF SUSTAINABILITY}

Much attention and analytical effort has been devoted in recent decades to the drama associated with explicit defaults on public debts, but as scholars have shown, such defaults are nothing new. ${ }^{14}$ More unexpected perhaps is the fact that more highly leveraged sovereigns have been able to borrow so cheaply in recent years; given that they can, still larger increases in public leverage are likely over the coming decades.

The US government has recorded budget deficits totaling \$7.6 trillion in the past decade (2006-15); nearly 25 percent of total spending in this time has been financed by loans instead of tax revenues, nearly quadruple the 6 percent share of spending that was borrowed in the post-World War II decades through 2005. For comparison, 35 percent of US spending was borrowed during the Great Depression (1930-39), and 51 percent during its involvement in World War II (1941-45). Looking ahead, budget analysts project that US federal deficits, despite having narrowed somewhat in recent years, will resume widening over the coming decade, such that total US public debt will continue increasing, both in absolute amount and relative to GDP (Figure 1.8).

Fast-rising public debts will remain a potential problem and thus a crucial issue in the coming decades. Welfare states will continue to face 


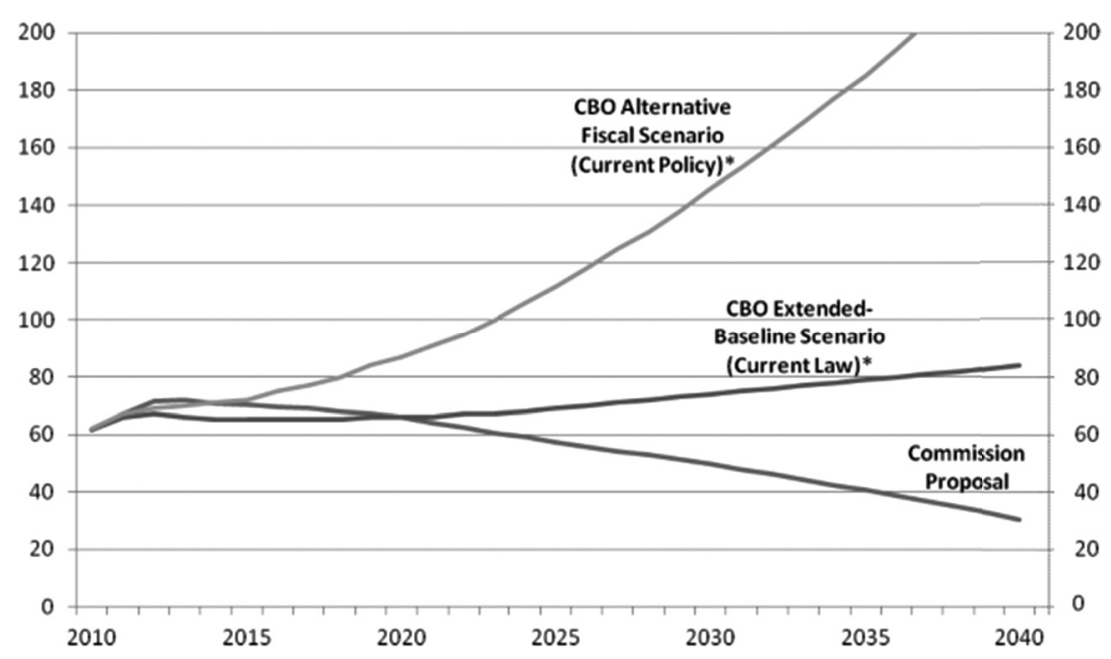

Notes: * Includes only federal debt held by the public, which is less than gross debt. $\mathrm{CBO}=$ Congressional Budget Office.

Source: National Commission on Fiscal Responsibility (2010, p. 10).

Figure 1.8 Three projections of the US debt*/GDP ratio (leverage), 2010-40

slow-growing tax revenues due to stagnant (because overtaxed and overregulated) economies, while spending still larger sums on dependent and aging populations. Public debts will continue to mount so long as democratic welfare states keep growing with no effective constitutional limit. Until then, public finance scholars can only try to best gauge the outer limits of public credit - that is, public debt capacity. In Chapter 5, I examine some initial efforts along these lines. But in the next three chapters I first assess classical, Keynesian, and public choice conceptions of public debt.

\section{NOTES}

1. See the public debt databases of the IMF, World Bank, OECD, and BIS plus Tomz (2007), Abbas et al. (2011), Jaimovich and Panizza (2010), Das et al. (2012), Enderlein et al. (2012), Janus et al. (2013), Beers and Nadeau (2015), Bloch and Fall (2015), Dembiermont et al. (2015), and Bova et al. (2016).

2. North and Weingast (1989), Weingast (1997), and MacDonald (2003).

3. Bastable (1903), Birck (1927), Brewer (1989), Brantlinger (1996), Mueller (1997), Bonney (1999), Botticini (2000), Bordo and Cortes-Conde (2001), Schofield and 
Mayhew (2002), Stasavage (2002, 2003, 2007, 2011, 2015), Cahill (2010), Cardoso and Lains (2010), Graeber (2011), and Strangio (2013).

4. Webber and Wildavsky (1986), Shatzmiller (1989), Homer and Sylla (1991), Glaeser and Scheinkman (1998), Armstrong (2003), and Dyson (2014).

5. Nelson (1949), Jones (1990), Shatzmiller (1989), Glaeser and Scheinkman (1998), Reed and Bekar (2003), Brook (2007), and Cahill (2010).

6. The prejudice persists today: Pollin (1996), Hudson (2010), Krugman (2011a, 2014), Konczal (2013), and Baiman (2014).

7. Suter (1992), Coleman (1999), Skeel (2003), and Mann (2009).

8. Bordo and Rockoff (1996) and Esteves (2013).

9. R. Hamilton (1816), E.J. Hamilton (1947), North and Weingast (1989), Root (1989, 1994), Dickson (1993), Brewer (1989), Homer and Sylla (1991), Neal (1993), Bonney (1999), Hoffman and Norberg (2002), Stasavage (2003, 2007, 2011), Johnson (2006), Dincecco (2009), and Carey and Finlay (2011).

10. Boltho and Glyn (2006), Altman and Haass (2010), and Dincecco (2010).

11. Ross (1892), Bordo and Rockoff (1996), Sylla and Wilson (1999), Selgin and White (2005), Dove (2012), and Murphy (2013).

12. Timberlake (1978, 2012), Goodhart (1988), Toniolo (1988), Volcker (1990), Vaubel (1997), and Fry (1997).

13. Selgin and White (1999), Wood (2012), and Salsman (2013a, 2013b).

14. Eichengreen and Portes (1986), Suter (1992), English (1996), Sturzenegger and Zettelmeyer (2006), Kohlscheen (2007), Reinhart and Rogoff (2009), Oosterlinck (2013), Rampell (2013), Tomz and Wright (2013), Beers and Nadeau (2015), Altamura and Zendejas (2016), and Reinhart et al. (2016). 